\title{
The Management Practice of Higher Education Institutions: The Case in Private Institutions of Higher Education (PIHE) in Senegal
}

\author{
Boubacar Basse \\ Assane Seck University of Ziguinchor - BP 1540 Ziguinchor \\ *Corresponding Author: bbasse@univ-zig.sn
}

Copyright (C) 2015 Horizon Research Publishing All rights reserved.

\begin{abstract}
Among the difficulties that plague the flight of African companies are listed excessive centralization combining with loss of control of decentralized units, systematic interference by the holder of the share capital in the operational management of the company and preferential recruitment of staff based on a certain proximity to the founder leader. Based on a case study in the Senegalese private sector (private institutions of higher education), the author shows that the tools and methods of theoretical organization remain difficult to apply to the "raw" state in an African context. Far from being linked to African cultural depths, practices so observed can be eradicated through the implementation of a management consultation aimed at unlocking the potential of all staff members.
\end{abstract}

Keywords Management, Private Institutions of Higher Education, Business, Enterprise, Decentralization, Case Study

\section{Introduction}

The private institutions of higher education (PIHE) are businesses in their own right, subject to constraints of profit maximization. However they have many characteristics that stand above all the urgent need to reconcile the logic of financial profitability and teaching effectiveness, which remains the cornerstone of these 'special' companies. Even better, the head of School must meet a number of skills to cope with the complexity of its mission both "teacher" and manager of the company. The complexity so described sets the problem of management of the PIHE Senegal, like many African businesses sick of "bad management" almost unanimously recognized in the scientific literature relating to it.

We chose to focus research on specialized PIHE in tertiary trainings with the desire to maintain certain homogeneity in the study. Specifically, the following managerial issues came to our attention:
- The degree of formalization in the organizational structure and management processes;

- Decentralization of the company to alleviate the activities concentrated at the head office or the presidency;

- Coordination between different departments of education that operate in isolation without genuine cooperation;

- Management of the administrative and teaching staff, including recruitment, motivation and accountability.

The objective of this paper is twofold. It is first to clarify the problems faced by PIHE in their management. Then it comes to making a look back on African companies in a new context of globalization in order to glimpse the specificities. So the first part of the article focuses on the literature review based on the management of education in general and the management of African enterprises in particular. The second part focuses on the presentation of the methodology used, including the case study. The third part looks like a diagnosis, highlights the most significant managerial practices in the operation of PIHE. Finally, the last section finds in adequate tools and modes of organization "imported" to the African context.

\section{Conceptual Framework and Literature Review}

\subsection{Administration of Education}

The management of private higher education institutions (PIHE) is unarguably the management of education. Many authors (MurphyandHallinguer1989;Brunet, Brassardand Corriveau,1991) have speculated about the critical importance of the management of the establishment on the school effectiveness as measured by student achievement, the openness to innovation and team commitment in the educational development(Pelletier, 1996). In the same line, Diop (2009) conducted an investigation for the purpose of 
classification of 16 PIHE (including 2of our sample) the most prominent in terms of commercial awareness. The criteria used (Table 1) are sufficiently relevan to establish a scientific validation of training offered by PIHE.

Tamba (2009) also shows that PIHE are marked with:

- Feminization of the workforceto53\%withan average age of 23 years. Such a choice is justified by a desire to quickly finish their studies to be able to focus on their future household.

- a strong presence of the children of affluent classes in terms of their social origin(lawyers, judges, notaries, engineers, entrepreneurs, large traders, administration officials and the Private, doctors, pharmacists, senior officers Army, Customs, bankers etc.)

- the presence of foreigners from the sub-region, but also from Central and Eastern Africa.

Using quality criteria above, Table 2 provides a ranking of the most significant in terms of the recognition of CAMES and business reputation.
Table 1. classification criteria and schedule

\begin{tabular}{|c|c|}
\hline Criteria & Schedule \\
\hline CAMES *Recognition & 10 \\
\hline ISO 9001 Quality & 5 \\
\hline Existence of a Scientific Council Program Validation & 5 \\
\hline $\begin{array}{c}\text { Existence in the staff recruited teachers rank A (holders } \\
\text { or Lecturer teachers) }\end{array}$ & 5 \\
\hline Insertion rate of graduates & 5 \\
\hline Number of permanent teachers & 3 \\
\hline Teacher ratio (number of students per teacher) & 3 \\
\hline Success rate & 3 \\
\hline Exailable resources (practical training rooms, libraries) & 2 \\
\hline $\begin{array}{c}\text { applicable } \\
\text { Internet access }\end{array}$ & 2 \\
\hline Availability of a website from school & 1 \\
\hline Grand total & 45 \\
\hline
\end{tabular}

Source: Diop L. (2009) in LIFE (Green Environmental Information), No. 09 of January-February 2009, p.43

* The CAMES (African and Malagasy Council for Higher Education) is the structure for accrediting qualifications and promotion of higher education teachers in their career.

Table 2. Classification of PIHE

\begin{tabular}{|c|c|c|c|}
\hline Higher education institutions & Type of Training & $\begin{array}{c}\text { Total } \\
\text { Points }\end{array}$ & ranking \\
\hline $\begin{array}{l}\text { ESMPT(IMultinational Graduate School } \\
\text { forTelecommunication) }\end{array}$ & TelecommunicationsandICT & 38 & 1 \\
\hline ISM(Higher Institute of Management) & Economics, management, marketing & 37.5 & 2 \\
\hline IAM(African Institute ofManagement) & $\begin{array}{c}\text { Economics, management, marketing, computer } \\
\text { Science }\end{array}$ & 37.5 & 2 \\
\hline $\begin{array}{c}\text { SUP DECO(Graduate Business School } \\
\text { ofDakar) }\end{array}$ & $\begin{array}{c}\text { Economics, management, marketing, computer } \\
\text { Science }\end{array}$ & 35 & 4 \\
\hline UNIS(University of Sahel) & $\begin{array}{c}\text { Economics, management, } \\
\text { marketing,computersciences, exact sciences }\end{array}$ & 34.5 & 5 \\
\hline $\begin{array}{l}\text { ISSIC(Higher Institute of Sciencesof } \\
\text { Informationand Communication) }\end{array}$ & Communication,Journalism & 24.5 & 6 \\
\hline $\begin{array}{c}\text { ISCOM(Higher Institute of Business and } \\
\text { Management) }\end{array}$ & Economics, management, marketing & 23.5 & 7 \\
\hline $\begin{array}{c}\text { ESIMTEL(Graduate School of } \\
\text { Informatics,Management and } \\
\text { Telecommunications) } \\
\end{array}$ & $\begin{array}{l}\text { Economics, management, marketing,computer } \\
\text { science, exact sciences }\end{array}$ & 23 & 8 \\
\hline Saint - Michel & $\begin{array}{l}\text { Economics, management, marketing, computer } \\
\text { science }\end{array}$ & 22 & 9 \\
\hline UAHB(Amadou HampatéBA University) & $\begin{array}{c}\text { Economics, management,management, } \\
\text { marketing,sciences }\end{array}$ & 22 & 9 \\
\hline $\begin{array}{c}\text { AFI(AssistanceTrainingInformation } \\
\text { Technology, University of the Enterprise) }\end{array}$ & $\begin{array}{l}\text { Economics, management, marketing, computer } \\
\text { Science }\end{array}$ & 18 & 11 \\
\hline $\begin{array}{c}\text { ESUP(Graduate School of Business and } \\
\text { Management) }\end{array}$ & Economics, management, marketing & 18 & 11 \\
\hline $\begin{array}{l}\text { IPD(Institute ofPopulationand } \\
\text { DevelopmentThomasSankara) }\end{array}$ & Economics, management, marketing & 18 & 11 \\
\hline $\begin{array}{c}\text { MIT(Higher Institute for Management } \\
\text { Training) }\end{array}$ & $\begin{array}{l}\text { Economics, management, marketing, computer } \\
\text { science }\end{array}$ & 15 & 14 \\
\hline $\begin{array}{c}\text { ETICCA(School ofInternational Commerce, } \\
\text { Business Communication) }\end{array}$ & Economics, management, management, marketing & 14 & 15 \\
\hline $\begin{array}{l}\text { ETSHOS(Technical School for } \\
\text { Stewardessesand Secretaries) }\end{array}$ & Economics, management, marketing & 14 & 15 \\
\hline
\end{tabular}

Source: L. Diop(2009) in VIE (GreenEnvironmental Information), No. 09 of January-February 2009, p.44 
The manager of Education has the distinction of being the "first teacher" of his/her establishment. In addition he is required to a management role. In doing so, it falls on him/her to master four areas of competence outlined in the report of the National Commission on Excellence in Educational Administration (1987) cited by Pelletier(1996).These are:

1. Functional field that combines the skills necessary to operate an educational organization, taking into account the educational mission and programs of study;

2. Study programmes field that describes the skills surrounding the mastery of curriculum, instruction and technology education programs. It reflects the support services, the school organization and development activities.

3. Interpersonal field that is associated with the importance of knowing how to maintain satisfactory interpersonal relationships. Given that these contribute to the achievement of personal, professional and organizational goals;

4. Scope of context that represents the various forces of influence of the school namely the intellectual, ethical, cultural, economic, and political and governmental forces.

The multitude of scopes so described shows the complexity of the managerial work of PIHE responsible. It raises the question of the nature of the training to be received by the head teacher to fulfill his / her mission.

All in all, contrary to the public institutions of teaching, private establishments of higher education are organizations with lucrative goal i.e. companies. In Senegal, they are generally created and managed by private promoters (individuals) independent of the State. From this point of view, they are distinguished from the other organizations (utilities, public universities, trade unions, associations, clubs sporting, etc... ) by research even the maximization of the pecuniary profit. Moreover, these particular companies, within the meaning of Dayan and al. (2005), offer commercial services to traders training. They are of different sizes (small, medium and large)generally measured using quantitative criteria like the turnover represented by the registration fee and of schooling paid by the students, the capital of the company, the number of employees, etc.... From this point of view, the PIHE pursue objectives of economic and financial profitability, market share ... in the same way as firms in other sectors of activity

\subsection{The Management of African Enterprises}

The management of African companies is highly criticized in almost an unanimous momentum and repeatedly by a number of authors and researchers who usually analyzed it under the Western managerial models. So if d'Iribarne (1990) denounces an impossible decentralization linked to "hostile" cultural traits. Dia (1991) finds a traditional style of leadership that engenders failure of African enterprises, often unprofitable, uncompetitive and ephemeral. According to Tsika (1995), these companies face a "DIY Manager" arising from ignorance, for most entrepreneurs, of the modern management techniques (accounting, personnel management, sales techniques, etc.). As for Hernandez (2000), he argues that the African management, dedicated in continental model, is marked by strong hierarchical relationships associated with "paternalistic" and protective behaviors for the company's employees. "While acknowledging the "African management" undeniable advantages as a factor of social cohesion, security and strength to the members of the organization, Meier (2008) points out that this type of organization develops the cult of the leader and strong relationships dependencies that are contrary to the personal development of employees. D'Iribarne (1990) sees a problem here at the conduct of men marked by an almost constant demotivation, excessive centralization combined with a loss of control of decentralized units, a procedural burden associated with a heavy hierarchy and finally a strong resistance to change the status quo. Thus, according to Henry (1991) quoted by Meier (2008), the African entrepreneur is similar to a head of the family or clan that controls the key positions of the company and centralizes decisions. This means therefore that this management model is based on a family company design with patriarchal social relations (Etounga Manguelle, 1991, quoted by Meier, 2008).

\section{Research Methodology}

This research was based on the case study of eight (8) private higher education institutions (about a hundred!) in order to analyze the data relating to facts observed in managerial practices, consistent with the problematic of the study. Despite some little differences related to the specificities of each PIHE the methodological approach was basically the same for the eight (8) institutions. This sample is representative of the diversity of private institutions of higher education in Senegal, taking into account criteria such as:

-The type of institution(school, institute or private university);

-Training Offers primarily focused on the service;

-Geographical location (Dakar and Ziguinchor);

-Size(share capital, number of students ,number of permanent teachers).

Our choice of the case study is guided by the interests of simplification and clarity Bonoma (1985)cited by Evrard, Pras and Roux (2003) defines it as "a description obtained directly from a managerial position ,based on interviews, archives, observation or other sources of information, constructed to account for the situational context in which the behavior fits.

This position is in line with the approach of Yin (1989) that the case study is an empirical research that investigates a contemporary phenomenon in a real context, when the boundaries between phenomenon and context are not clear 
and in which multiple empirical sources are mobilized. Furthermore, this rigorous research method applicable to the study of organizations is part of a qualitative and inductive logic aiming to construct a theory based on the experience of actors (Hlady-Rispal, 2000). The case study also allows the generalization of the results, which is a guarantee of scientific nature(David, 2003).

We also plan, in the frame of this research, to observe and interpret existing coincidences on managerial practices including the internal organization, the operation of the hierarchy, the horizontal relationships between services of eight private institutions of higher Education (PIHE) studied. Data collection is done by passive observation and interviews with administrative and teaching staff as well as student from the eight PIHE studied. The data is analyzed by purely qualitative interpretative methods.

\section{Presentation and Analysis of Results}

\subsection{The Internal Organization}

The observed dysfunctions in the internal organization are mainly due to the difficulty of the company to delegate responsibilities to the hierarchy. But there is in this business a "job description" that formally establishes reporting relationships between different members of the organization by setting the prerogatives of each. The hierarchical superiors scalar chain is often "short-circuited" by employees who allow themselves to inform the President directly on behalf of a slogan discreetly conveyed within companies, "here there is only one leader, it is the President». Therefore, managers of the hierarchy acting as intermediaries between the strategic apex (Chairman) and the operational center (teachers) are in positions of responsibility with pompous and rewarding titles but truly without power of decision. Yet in the responsible PIHE speeches, it is still recognized (in theory!) these line managers can make decisions concerning the exercise which "cannot be challenged, whatever the consequences." However, in practice, any act done by these functional directors, is subject to the appraisal of the President. Otherwise beware offenders! He added that these functional managers live permanently "in crisis" because of unforeseen activities imposed by the supervisory management who blow up their schedule. Short-term emergencies prevent them from taking a step back to focus on reflection and real productive work. Stressed and exhausted, they lead a professional life that impinges on their privacy. As for presidents, they often indulge in a dispersion of heavy responsibilities they assume somehow outside their businesses. To this end, they still face the difficult equation of accumulation of all these functions with a desire to control everything in their establishments; they are also not always present. How many important people have seen their appointments with the hierarchy delayed or postponed at the last moment due to unavailability of it?

On the commercial side, some tasks are poorly assumed due to a lack of formalization of a coherent policy. This is mainly the case of debt collection practices and business reminders, often conducted in an "awkward" manner if we stick to the complaints of customers. They disagree, in a nearly unanimous enthusiasm, the entry of "treasurers" in most institutions, in full teaching session, armed with a list of debtors students, asking them to leave the classroom on the grounds of non-payment of tuition on due date. Also, an additional control is introduced at the entrance of some institutions in order to prevent access to the debtors. These practices are still hotly contested by clients injured in their honor and dignity, who would have liked a discretionary treatment of their personnel file. They are at the origin of many of PIHE studied disaffection in favor of competitors who have "less" degrading commercial methods of recovery. All told, the relatively high amount of outstanding loans is attributable not only to PIHE employees' indifference to strategic and business issues but also to a lack upstream of effective mechanisms for securing payments.

\subsection{The Human Resource Management}

According to Liger (2004), HR marketing is vested in the Director of Human Resources activity to tap into marketing techniques to achieve its mission of attracting and retaining quality individual profiles. Relying primarily on the employer image, HR marketing aims to attract candidates and retain employees. From this point of view, the employee is considered a client subject of special attention in terms of actions of seduction. However, the reality prevailing in the PIHE is different. In fact, to the source of demotivation of functional executives of the company, related to the lack of real decentralization, adds another frustration due to unequal treatment with respect to the level of education, professional experience and salary. This inadequacy between contributions and remunerations with the chapter of the theory of equity involves often aberrant discriminations compared to the wage treatment of the executives, if we stick to the "information leaks" from financial services. Unlike the public sector, the private sector, including the PIHE use no objective salary scale applied Impersonally To Employees. Compensation Is Totally Free and at the Discretion of the Officer, Provided It Meets The Minimum threshold set by the Labour Code in force. Discrimination between staff members is also linked to the existence of two categories of employees in the company: "Anonymous" on one hand and those with close family ties with the President, on the other. The latter, with their proximity to the master chef, are repositories of his "total» confidence but mistrusted by the anonymous workers who see them as "the eyes and ears of the President." Therefore, these "privileged" employees arrogate exceptional benefits from their special status which, often, allows them arrogant attitudes with other staff members who resign themselves to support such 
misbehavior for fear of reprisals in the sense of losing their jobs. The existence of the related personnel to the President is also a taboo subject which it is important not to mention to foreign partners, at the risk of sanctions. It would look very bad, given hints of nepotism that may arise.

\subsection{Financial Management}

Financial Management is subject to opacity purposely maintained by the financial and accounting services on the one hand and the President on the other. If the shareholding companies are an open secret, profits annually remain at the sole discretion of the parties involved. Workers who contributed to the achievement of these financial results are not entitled to any accompanying information, let alone a performance-related incentive. Such an incentive would be justified because at the beginning of each year and in most cases, department heads (Master of Science in Management, specialized Masters Continuing Education or Professional licenses if applicable) are required by objective numbers annual business set by the hierarchy on a proposal from the Finance Department. Ex-post evaluation, which occurs after the close of registration, allows to take stock and to detect differences between forecasts of revenues and achievements. As such, the monthly meetings called "coordination" are privileged by the President to openly congratulate favorable variances or contrary to mark his disapproval of unfavorable variances before demanding explanations. Thus, information on the net results is even a taboo subject being understood that for all PIHE studied, the founding President is the main recipient. This is all the same for expenses incurred by the President as part of the operation and also for its own account. $\mathrm{He}$ is the only officer of the institution's budget and regularly reviews expenditures incurred for the benefit of other cost centers of the company.

\subsection{The Launch of New Courses: Market Research}

Business intelligence (BI) in the PIHE is essentially to monitor the competitive environment in order to grasp the opportunities and possibly to remove threats. This watch is therefore an informal and cross all the components of PIHE activity which they may report, at any time, to the hierarchy to inform of vital information about a competitor, a market trend, recurring recriminations customers, etc. It is then up to the President to judge the opportunity to seize the right person in order to act accordingly.

This BI reflex is so pregnant in the mind of PIHE staff that this activity tends to supersede the market research for launching new courses. During the period of our intervention, several new courses were opened in most PIHE without proper market research. The reason derives essentially from the expressions of interest for a particular training. Prospects, either by phone or e-mail or directly come to the site to inquire about the existence of a Master or specific license. The recurrent and repetitive nature of such expressions of interest is apparently significant enough to be a reason for launching the requested training. But it turns out that between the time of the formulation of the request and that of the actual launch of the training by the PIHE, many customers went elsewhere to meet their learning needs. So, how much training has been a craze from prospects were left ultimately with a number of real customers well below initial expectations?

\section{Discussion and Managerial Implications}

Inadequate tools and modes of organization "imported" prove unsuitable as being plated without remodeling, so without sociocultural roots in the African context (Diagne, 2009). This approach of "one best way" must give way to the contingency theory that there is no good model in itself. Good managerial model is the one that puts the company in accordance with its environment. The main problems relate to the difficulty or impossibility to decentralize the company to exclude from the field of management power holders if they do not have the skills to fulfill this mission and finally to bet exclusively competency in recruitment at the expense of purely personal considerations with hints of nepotism.

\subsection{Decentralization, a Difficult Challenge}

Decentralization of responsibilities in African businesses is still a luxury applied by few managers concerned with the "normal" operation of their businesses. Based on a case study in a public company of Cameroon, d'Iribarne (1990) shows that excessive centralization seems to be a rule in the management of African businesses. This is as much due to the refusal of the tutelage of delegating decision-making power as to a resistance from subordinates to decentralization. Excessive centralization of responsibilities is justified by the management by incompetent subordinates. Competence, broadly defined, includes the technical skills and confidence to handle complex and confidential files. All the more since the company including public is still perceived as a space to share resources, a means of financing a political clientele, a funds provider for monstrous show of force, a place to promote the clan (Kasse, 2005). As for the hostility of the subordinates to a "reasonable" decentralization, D'Iribarne (1990) equates it to their fleeing from responsibilities, especially when it comes to making decisions about the status of staff.

In this regard, the exercise of disciplinary powers and even coercion faces a fear of offending his colleagues, with all the other consequences that may arise in terms of interpersonal relationships. In this context, it is very important to appear as friendly rather than be in a difficult situation by using his authority to correct abuses. The refusal expressed by program managers in PIHE to take responsibility for the breaking of collaboration with some "unproductive" part-time teachers is well within the logic of fear of sanction. However, sanctions, positive or negative, are a requirement 
of running a company that wants organized, governed by standards and ethics. Because the value of the standard is measured by the sanction which strikes the non-compliance (Diby, 2007).

\subsection{Power and Management}

The review of the management practices in the EPES reveals a weary finding by its recurrence: the active participation of the founder of the company to the management. Thus, there many cases of businesses in which the founder occupies the position of CEO. In Senegal, several private television channels are perfect illustrations among other examples in all economic sectors. However, referring to the orthodoxy of the management, the phenomenon is so maligned for the existence of most probable conflicts between ownership and control as much as for the inability of the contractor to provide an efficient management of the entity. This is why Fongang (2001) said that the shortcomings of the owners of small and medium enterprises (SMEs) in information, education and experience are a fundamental constraint to the development of the potential of these entities.

Going back to the motives of owner-managers to interfere in the management of their affairs, we must admit that the lack of trust in employees is the main explanation for the non accountability of these. In terms of corporate governance, the separation of ownership and control is a source of problems. Because when leaders are just a tiny stake in their company, they tend to have low incentive to act in the interests of shareholders. Conversely, a strong involvement of leaders in the capital of the company can theoretically have the effect of boosting the bottom line. This cause and effect relation is far from being established in many African businesses if we are to believe Fall (1986) cited by Fongang (2001) that equates the leaders of these companies to self-made men with very little awareness of accounting rules and confusing their wealth with those of the company or equating sales to profits. This irrational behavior in managing the assets of the company is the daily lot of PIHE studied especially in these entities, especially when the President remains the largest shareholder. Thus, apart from their "extremely" high salary compared to personnel emoluments, Presidents delight to fund many expenses that often have no connection with the operation, but fall unquestionably on community constraints redistribution, religious obligations, ostentatious expenses on valuation of financial resources made during the activity (Labazée 1988). If these financial transfers to collective membership push the economic rationality into the background (Mahieu, 1990), we must recognize that they allow to increase the "wealth in people" that is to say the number of parents, dependents and customers likely to work for the President or to do him favour. The relatively high number of these tends not only to ensure the moral authority of the President on them but also to implement clientelist strategies to take advantage of the enormous personal submissions acquired from multiple communities like professional groups, religious or political groups, the originating associations, neighborhoods ... (Labazée 1992). However, in a culturalist approach Labazée (1992) recognizes the economic justification for these 'social' investments as well as the extra-economic expenses incurred by firms in industrial countries to celebrate their greatness or their leaders. Moreover they result from community ties that often remain the only means of access to economic field socially constituted.

\subsection{A Social Balance that Devotes the Primacy of Confidence over Competence}

The human resource management is still embryonic in many African companies including PIHE despite the existence of tools like the job description (Diagne, 2009). In this regard, it should be noted that the family hiring, or more broadly, the preferential recruitment remains a well-established practice in Africa. It stems from a lack of trust or distrust in the business between people from different regions (Ponson, 1995). It is the same with the hierarchical arrangement of the workforce that reflects often social links between the inside and the outside of firms (Labazée 1995). This means like Hugon (1995) that the African business is crossed by transverse hierarchies and several types of solidarity: family, ethnic, religious ... As a result, the employment relationship is not a commercial relationship based on employment contracts between the employers and their employees. It is rather a relationship of dependence in which the act of allegiance to the head is offset by protection from the latter. Henry (1991) cited by Diagne (2009) recognizes that "through an ethnic or family-type hiring, leaders fulfill a duty vis-à-vis their own, while focusing their subordinates personally dedicated to him. As "bosses", they then give broad protection that extends to solving personal problems, in exchange for a total service that can include tasks as an informant or "factorum." Thus, according to Diagne (2009), this described ethno-tribal phenomenon devotes excessive or exclusive preference for people who share the same collective belonging. In addition, it treats those who are not part of the system as "foreign" or "enemies" whose presence poses a threat to the cohesion and continuity of the group. Analyzing management in two dimensions, namely the commitment (the interest centered on the production) and cooperation (interest centered on the human factor), Blake and Mouton (1985) cited by Hernandez (1989) show that to obtain harmonious interpersonal relations, the African is typically willing to make sacrifices in terms of production efficiency.

In addition to these clan or community logic, Kasse (2005) noted a change with the emergence of new cultures of solidarity based not on common belonging to a floor or blood ties, but rather on interest groups on singular identities backed by individual trajectories.

In any event, the primacy of trust and proximity relationship over anonymous contracts confirms the prevalence of migration on Tenure and prohibits economies 
of scale.

However, under the assumptions of neo-institutional school, ethnicity economic activities are one way to reduce costs by customizing and building relationships on trust. The savings here are made on recruitment costs (internal or external through headhunters). Furthermore, the preferential recruitment inflects the de - facto game advancements, promotions and salary increases determined by agreement (Labazée 1992).

Another major issue related to the preferred hiring is probably the social balance essential to the achievement of profitability goals of the company. If one believes Labazée (1992), the logic of communal rights and obligations is part of a strategy explicitly targeted at reducing labor costs and especially the risk of unionization

The absence of unions in many personal "family" companies including EPES in Senegal is thereby justified. Thus, despite its nepotism flaws, preferential recruitment is a shield against union activity and, in turn, a guarantee of social equilibrium. It should be added, rightly, a flexibility of employment, for social juniors without employment contracts, are easily evicted if they are unproductive or when the company is experiencing a cyclical downturn of activities.

You still have to put the scope of such discretion into perspective because, in such circumstances, the legitimacy of community constraints makes the dismissal an extremely rare procedure. Especially since social pressures are perfectly acceptable when the contractor is choosing his/her staff. These are part of an ethics based on rights and obligations in which the Enterprise becomes an essential part of a strategy of domestic production. To reconcile the legitimacy of community constraints and the need for optimal management of human resources, some developers come to move social pressures outside the company. Thus, material and / or financial assistance, participation in ceremonies, support for school dependents become counterparties limitation or restriction made on the preferred recruitment (Labazée 1991). Especially since the absorption capacity of the labor force by any company remains structurally limited.

\section{Conclusions}

The observation of managerial practices in the PIHE, object of our research, suggests a view that the corporate executive has to defend the territory and the position he occupies. Thus, decentralization as well as objective and impartial staff recruitments is still difficult challenges for African business to take up. It is therefore important to note some changes in the relationship of the society and the firm, generational alternation of managers being of a help. All in all, far from being related to African cultural depths, some practices observed derive more from the inability of capital owners who insist on directing "their" company without actually having the skills for. It is therefore important to implement a consultation management as advocated in the values of African civilization and likely to enhance the potential of all staff (sweeper to CEO!) so as to increase the efficiency of the group and reach the common goal. Also, the implementation of change must follow an action plan to prepare and establish a policy framework. According to Noyé (2005), this action plan is to:

$>$ Define the objectives of the action

$>$ Specify the action to be undertaken

$>$ Clarify responsibilities

$>$ Establish deadlines

> Identify ways to monitor and evaluate the results.

This new managerial policy, more participative, gives the manager a status of an educational leader and not of an authoritarian decision maker.

It falls in line with Diby's proposal (2008) that 'managing is to get the job done while doing it yourself, intending to lead to the highest and best possible performance. "From there, the participatory approach induces the idea of exchanges, ebb and flow in decision-making and its implementation.

\section{REFERENCES}

[1] R. Blake et J. Mouton. Les deux dimensions du management, Paris, Editions d'Organisation, 1985

[2] J. Bonoma.Case research in marketing; opportunities, problems and a process, Journal of Marketing Research, 14, $199-208,1985$

[3] L. Brunet, A. Brassard et L. Corriveau. Administration scolaire et efficacité dans les organisations, Ed. Agence d'Arc, Montréal, 215 p., 1991

[4] A. David. Etudes de cas et généralisations scientifiques en sciences de gestion, Revue des Sciences de Gestion, n39, p.139-166, 2003

[5] A. Dayan et al. Manuel de gestion, Ellipes / AUF, Vol 1 \& 2, 2005

[6] A.L.Dia. Le management africain: mythe ou réalité, in Revue Internationale P.M.E, Presses Universitaires du Québec, Vol 4, $\mathrm{N}^{\circ} 1$, pp. $29-48,1991$

[7] B. I.Diagne, () «l'entreprise étranglée», Dakar, Editions CEMA. 2009

[8] C.K. Diby. Management des services publics en Afrique, Hachette. 2007

[9] L.Diop. Le classement des établissements d'enseignement supérieur privé au Sénégal, in VIE (Vert Information Environnementale), N09 de janvier-février, pp.43-44;Faculté des Sciences et Techniques de l'Université Cheikh Anta Diop, Laboratoire de Rayonnements Naturel et Artificiel (LARNA), 2009

[10] S. Ellis et Y-A. Fauré. Entreprises et entrepreneurs africains», Karthala-ORSTOM, 1995 
[11] D. EtoungaManguelle. L'Afrique $a-t-$ elle besoin d'un programme d'ajustement culturel?Les Editions Nouvelles du Sud, 1991

[12] Y. Evrard, B. Pras et E. Roux. Market, Etudes et Recherches en Marketing, Dunod, 3ème édition. 2003

[13] A. Fall. Le saut d'obstacle des PME in le quotidien dakarois «Le Soleil» du 25 nov. 1996

[14] D. Fongang.La P.M.E. africaine face à la mondialisation, , Presses Universitaires d'Afrique, Yaoundé, 2001

[15] A. Henry. Vers un modèle du management africain, Cahiers d'études africaines, vol. XXXI (4),n124,pp.447- 473, 1991

[16] E. M. Hernandez. Essai d'approche anthropologique de la gestion de l'entreprise informelle africaine, Revue française de gestion, PP. 123-134, 2000

[17] E.M. Hernandez.Le management des entreprises africaines, Ed. L'Harmattan, Paris, 1997

[18] E.-M. Hernandez. L'entrepreneurship féminin en Côte d'Ivoire, Etude, Faculté des Sciences Economiques d'Abidjan, 1989

[19] M. Hlady-Rispal. Une stratégie de recherche en gestion: l'étude de cas, Revue Française de Gestion, janvier - février, p.61-70, 2000

[20] P. Hugon.Les entrepreneurs africains et l'analyse économique, in Stephen Ellis et Yves A. Fauré, pp.375-393, 1995

[21] P.D'Iribarne. Face à l'impossible décentralisation des entreprises africaines, Revue Française de Gestion, septembre-octobre, p. 28-39, 1990

[22] E. H. Kassé. Manager, c'est résister», Editions Casset, Dakar, 2005

[23] P. Labazée. Le monde des affaires burkinabé: typologie d'un milieu d'entrepreneurs africains, in Stephen Ellis et Yves A. Fauré.Entreprises et entrepreneurs africains», Karthala et ORSTOM, Paris, 1995

[24] P. Labazée.Organisation sociale et stratégies économiques des réseaux marchands transfrontaliers. Le cas des échanges entre la Côte d'Ivoire, le Mali et le Burkina Faso, Rapport
ASP n4, CNRS-ORSTOM, Paris, 1992

[25] P. Labazée. L'entreprise africaine. Un terrain anthropologique à explorer, Cahiers d'études africaines, vol. XXXI (4),n124, pp.533- 552, 1991

[26] P. Labazée. Entrepreneurs et entreprises au Burkina Faso, Karthala, Paris, 1988

[27] P. Liger. Le marketing RH, Dunod, Paris, 2004

[28] F.-R. Mahieu. Fondements économiques de la crise africaine. Entre pression communautaire et marché international, L'Harmattan, Paris, 1990

[29] O. Meier. Management Interculture, Dunod, 3ème édition, Paris, 2008

[30] J. Murphy et P. Hallinguer. A New Era in the Professional Development of School Administration: Lesson from Emerging Programmes", Journal of Educational Administration, vol 27 (2), 1989

[31] National commission on excellence in Educational Administration. Leaders for America's Schools, University Council for Educational Administration, 65 p., 1987

[32] D. Noyé. Conduire un plan d'action jusqu'au résultat, Insep Consulting, 2005

[33] G. Pelletier. Le gestionnaire, le leader et l'artiste, Revue Française de Gestion, janvier -février, pp.44-57, 1996

[34] B. Ponson. Entrepreneurs africains et asiatiques: quelques comparaisons, in S.Ellis et Y.A. Fauré; pp. 99 - 104, 1995

[35] A. Tamba. L'enseignement supérieur privé au Sénégal» in VIE (Vert Information Environnementale), N09 de janvier-février, pp.39-41; Faculté des Sciences et Techniques de l'Université Cheikh Anta Diop, Laboratoire de Rayonnements Naturel et Artificiel (LARNA), 2009

[36] J. Tsika.Entre l'enclume étatique et le marteau familial: l'impossible envol des entrepreneurs au Congo, in Stephen Ellis et Yves A. Fauré. Entreprises et entrepreneurs africains, Karthala et ORSTOM, Paris. 1995

[37] R.K. Yin. Case study Research Design and Methods, Sage, Newbury Park, 1989 